\title{
A new Phanerozoic carbonatite complex in southern West Greenland
}

\section{Karsten Secher and Lotte Melchior Larsen}

The airborne radiometric survey carried out in 1975 and 1976 in West Greenland (Secher, 1976, 1977), was followed in 1977 by field work on the ground. Areas with anomalous high radioactivity, detected during the airborne work, were examined using helicopter and handborne scintillometers. Between the valleys Arnangarnup kûa and Sarfartô, $60 \mathrm{~km}$ SSW of Søndre Strømfjord Air Base, a cluster of anomalies were shown to be related to a conspicuous area of carbonatite rocks now referred to as the Sarfartoq carbonatite complex (fig. 18).

The complex has an uneven elliptical outline, comprising a core area $\left(15 \mathrm{~km}^{2}\right)$ and a marginal zone $\left(75 \mathrm{~km}^{2}\right)$. The core has the shape of a steeply dipping cone, slightly flattened in a NE-SW direction. The centre of the complex is located in the middle of a valley and is poorly exposed. Kimberlites and associated carbonatite rocks (mainly dykes) in the area between Holsteinsborg and the actual area are mentioned by Bridgwater et al. (1976) and Scott (1977). The Sarfartoq carbonatite complex is situated $125 \mathrm{~km}$ north-east of the Phanerozoic Qaqarssuk carbonatite complex near Sukkertoppen (Nielsen, 1973; Secher, 1977).

Field work in 1977 has been concentrated on establishing the boundaries of the complex and obtaining an idea of the distribution of the radioactive elements. For this purpose a detailed geochemical sampling programme was carried out in the area covering the complex.

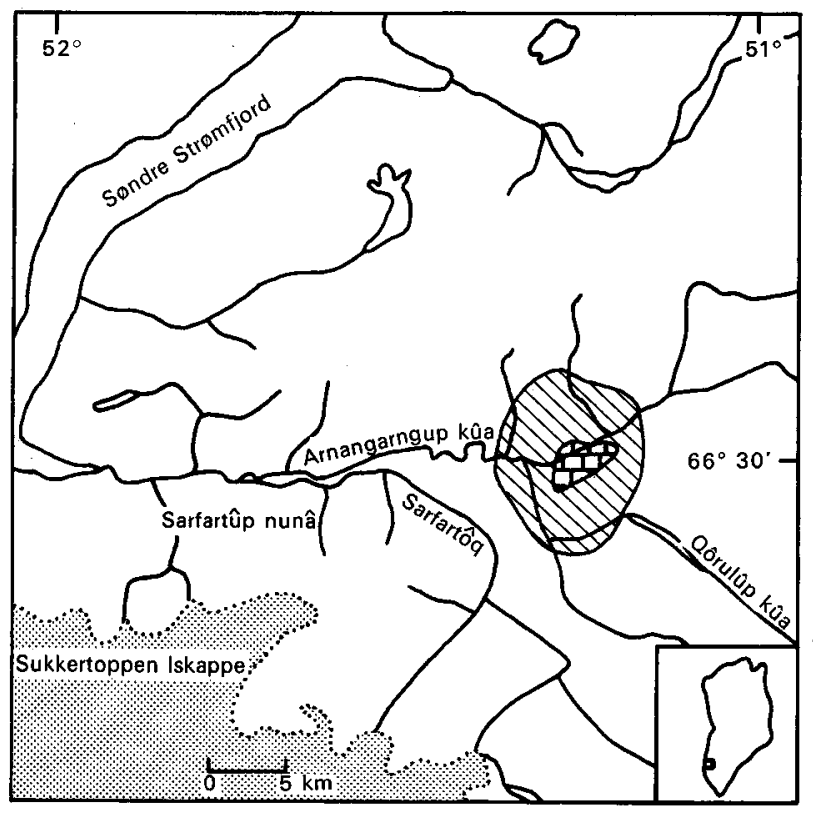

Fig. 18. Sketch map of the area south-east of Søndre Strømfjord, showing the Sarfartôq carbonatite complex. Dotted line: limitation of ice; brick symbol: the core zone; hatched: the marginal zone. 
Future work will involve more comprehensive studies of the structure, petrology and economic potential.

\section{Lithology}

The Sarfartoq carbonatite complex is situated in the transition zone of the Nagssugtoqidian boundary, and is surrounded by granodioritic gneisses with layers of basic rocks. The central core of the complex comprises carbonatites ( $20-40$ per cent of total rock volume) and various kinds of fenitised rocks. The marginal zone, more or less concordantly surrounding the core, consists of gneisses and amphibolites penetrated by discordant $5-100 \mathrm{~cm}$ wide dykes of carbonatite, various types of carbonatite breccias and agglomerates, and calcite veins. These dykes either radiate from the centre and have steep dips, or are tangential to the core outline with varying dips. The radiating dykes appear to be dominated by the breccias and agglomerates. The host rocks of the marginal zone are frequently altered due to cataclastic deformation, hematitisation, limonitisation and locally slight fenitisation. Their overall colour is a deep red-brown, in places with a white coating of secondary monohydrocalcite.

Within the core the two main rock types can be subdivided macroscopically by the colour of the weathered surfaces.

\section{Carbonatite group}

Light brown to red-brown I: Carbonatites with or without apatite and mica; sometimes pegmatitic. Light brown II: Magnetite-carbonatite with or without apatite.

Dark brown to black III: Ultramafic rocks with or without magnetite.

\section{Fenite group}

Light to dark brown IV: Silicocarbonatite, mixed carbonatite and altered gneiss. Brown to green V: Ultramafic rocks with or without pyrochlore.

Apatite is very common in tabular crystals up to $2 \mathrm{~cm}$ long, making up 5-20 per cent of rock types I and II. Magnetite is always present as euhedral crystals up to $3 \mathrm{~cm}$, and in layers making up to 80 per cent of rock types II and III. Magnetite is also observed as megablasts up to $15 \mathrm{~cm}$ across in type II. Rock types I and II are found as layers or sheets $0.5-5 \mathrm{~m}$ wide, in which type III occurs as lenses and thin layers. A gradual transition between types I-III exists. Rock types IV and V are mixed together in an irregular manner and are always cut by types I-III. Type V is characteristically apple-green in colour with patches and masses of nearly compact brown-yellow pyrochlore.

Within the marginal zone the following rock types belonging to the complex can be separated macroscopically by the colour of the weathered surfaces.

\section{Dyke rocks}

Light brown VI: Carbonatite with or without foliation.

Red-brown VII: Carbonatite breccias and agglomerates. Fragments of gneiss, amphibolite, ultramafics and carbonatites (core type). 
VIII: Carbonatite with no or few inclusions.

Olive brown IX: Kimberlites with ultramafic nodules.

Vein-fillings X: Calcite, siderite, rhodochrosite, hematite, pyrite; sometimes pegmatitic.

$\mathrm{XI}$ : Calcite, quartz, fluorite.

The rocks most commonly seen in the dykes are types VI and VII, in which foliation is more or less pronounced. The fragments of type VII are rounded to angular, and dominated by fenitised gneiss; there is a gradual transition into type VIII. Kimberlites (IX) are rather rare and have only been recognised at two localities. Vein-fillings are observed throughout the complex, often developed with a conspicuous zoning.

\section{Petrography}

Preliminary examination of thin and polished sections together with carbonate staining of rock slabs reveals that ferruginous dolomite is the main mineral of the core zone. Calcite is observed in some rocks of the core, too, where it is predominant in separate layers. Apatite and magnetite are locally important together with $\mathrm{Mg}$-arfvedsonite-richerite and phlogopite-biotite. Accessories include ilmenite, hematite, zircon, pyrochlore and pyrite. In the ultramafic rocks of the fenite group aegirine and zoned pyrochlore are main constituents with $\mathrm{K}$-feldspar, ankerite and $\mathrm{Nb}$-rutile as subordinate minerals. In the dykes of the marginal zone ankerite plays the dominant role in the matrix. Due to frequent inclusions of basement rocks, digested to varying degrees, several minerals occur. Among them the most prominent are alkali-feldspar, biotite-phlogopite, chlorite, aegirine, $\mathrm{Mg}$-arfvedsonite, quartz and zircon. Apatite, pyrite, barite and $\mathrm{Nb}$-rutile are characteristic minor constituents. More minerals, as yet unidentified, are present.

\section{Mineral chemistry}

Information on mineral chemistry is based on microprobe analyses of ten samples. The $\mathrm{Sr}$ content of the carbonates is $0.1-0.5$ per cent, highest in the core carbonates. The amphiboles and micas are all $\mathrm{Mg}$-rich. The magnetite is Ti-poor and zoned with decreasing Ti content outwards from crystal centre. Both magnetite and ilmenite contain some $\mathrm{Nb}$, most in ilmenite, where it is up to 0.5 per cent. $\mathrm{Nb}$-minerals are pyrochlore with $10-25$ per cent $\mathrm{Nb}$ and $\mathrm{Nb}$-rutile with up to 6 per cent $\mathrm{Nb}$. In addition, $\mathrm{Nb}$ is found in ankerite, biotite and aegirine from the ultramafic rocks of the fenite group. The pyrochlore is a clear U-Ti-type with 1-5 per cent $U$ and $2-5$ per cent $T i$, decreasing outwards in the zoned crystals. The content of rare earth minerals is notable and is confined to the dykes of the marginal zone, occurring in as yet unidentified minerals.

\section{Radioactive mineralisation}

The airborne survey revealed several localities with clusters of anomalous high radiation, all situated within the marginal zone.

The general background radiation level is about three times higher in the marginal zone than in the surrounding basement rocks, while in anomalous areas levels reach up to 10 
times the background of the basement rocks. Field studies demonstrated that the radiation is related to joints and shear zones with strong hematitisation, and in a few cases to carbonatite dyke types VI and VIII.

Within the core zone several radioactive mineralisations were detected using a hand scintillometer, mainly in the south-eastern part. Here the radiation is related partly to the carbonatite type I and partly to the pyrochlore-rich ultramafic rock in the fenitised surroundings.

Analyses (DNA) of some representative material showed a content up to $340 \mathrm{ppm} \mathrm{U}$ in the pyrochlore-rich ultramafic rocks of the core zone, whereas carbonatites of this zone reach up to $50 \mathrm{ppm} \mathrm{U}$. Analyses for Th are still to be performed.

\section{Concluding remarks}

The Sarfartoq carbonatite complex situated at the Nagssugtoqidian boundary is probably a central intrusion of ferruginous dolomite carbonatite sheets or layers (rauhaugite), surrounded by a $2-4 \mathrm{~km}$ wide marginal zone of alteration which is penetrated by radiating and tangential younger ankeritic carbonatite dykes and breccias. These have possibly been emplaced in a fracture pattern generated by the pressure of ascending carbonatite material. Finally, the carbonatitic activity ceased with vein fillings of carbonates, fluorite and pyrite. Observed kimberlite dykes within the complex and in the adjacent area as far west as Holsteinsborg may be related to this carbonatite activity.

Rocks and minerals displayed in the Sarfartoq complex are characteristic of carbonatite associations. Richerite is also reported from the kimberlitic dykes of the Holsteinsborg area (Scott, 1977). However, the Nb-mineral assemblage is less common with $\mathrm{Nb}$ in carbonates and silicates. Mineralisations of radioactive and at least one younger phase of mobilisation and hematitisation. The principal radioactive mineral of the core zone is a uranian-titanian-pyrochlore, often associated with aegirine.

Age relations are uncertain at present. One kimberlite from the north-west part of the marginal zone has given an age of 548 $\pm 18 \mathrm{~m} . \mathrm{y}$. (Bridgwater, 1971). The discovery of fossiliferous material in loose blocks of quartz-carbonate rocks within the marginal zone (Peel \& Secher, in press) implies a younger age (Palaeozoic-Mesozoic?). Also, it is noteworthy that the Qaqarssuk carbonatite complex is situated close to another locality ('Fossilik', Poulsen, 1966) where Palaeozoic fossiliferous rocks occur.

\section{References}

Bridgwater, D. 1971: Routine K/Ar age determinations on rocks from Greenland carried out for GGU in 1970. Rapp. Grønlands geol. Unders. 35, 52-60.

Bridgwater, D., Keto, L., McGregor, V. R. \& Myers, J. S. 1976: Archaean gneiss complex of Greenland. In Escher, A. \& Watt, W. S. (edit.) Geology of Greenland, 18-75. Copenhagen: Geol. Surv. Greenland.

Heinrich, E. Wm. 1966: The geology of carbonatites. Chicago: Rand McNally \& Co, 555 pp.

Nielsen, B. L. 1973: A survey of the economic geology of Greenland (exclusive fossil fuels). Rapp. Grønlands geol: Unders. 56, 45 pp. 
Peel, J. S. \& Secher, K. in press: A second occurrence of fossiliferous rocks from the Precambrian shield of southern West Greenland. Rapp. Grønlands geol. Unders.

Poulsen, V. 1966: An occurrence of Lower Palaeozoic rocks within the Precambrian terrain near Sukkertoppen. Rapp. Grønlands geol. Unders. 11, p. 26 only.

Scott, B. H. 1977: Petrogenesis of kimberlites and associated potassic lamprophyres from central West Greenland. Unpubl. Ph. D. thesis, Univ. Edinburgh.

Secher, K. 1976: Airborne radiometric survey between $66^{\circ}$ and $69^{\circ} \mathrm{N}$, southern and central West Greenland. Rapp. Grønlands geol. Unders. 80, 65-67.

Secher, K. 1977: Airborne radiometric survey between $63^{\circ}$ and $66^{\circ} \mathrm{N}$, southern West Greenland. Rapp. Grønlands geol. Unders. 85, 49-50.

\title{
Continued 1:500 000 reconnaissance mapping in the Precambrian of the Sukkertoppen region, southern West Greenland
}

\author{
J. H. Allaart, C. R. L. Friend, R. P. Hall, \\ S. B. Jensen and I. W. N. Roberts
}

The reconnaissance mapping programme for the 1:500 000 map sheet Frederikshåb Isblink - Søndre Strømfjord $\left(62^{\circ} 30^{\prime}-66^{\circ} 45^{\prime} \mathrm{N}\right)$, in the Godthåb-Sukkertoppen region that started in 1976 (Allaart et al., 1977), was continued in 1977. This summer's activity was concentrated in the areas between the inner part of Fiskefjord and Taserssuaq, from Taserssuaq to north of Majorqaq and from Søndre Isortoq to Evighedsfjord (fig. 19). Between Fiskefjord and Søndre Isortoq detailed mapping has been carried out by geologists of Kryolitselskabet Øresund A/S during the summers of 1965-1976. The coastal areas have been investigated previously by GGU geologists (Berthelsen, 1960; Noe-Nygaard \& Ramberg, 1961).

The mapping team of five geologists, supported by two Bell G3 helicopters and by the GGU motor cutter $F$. Johnstrup, operated from a base camp at the head of the fjord Kangerdluarssuk, $30 \mathrm{~km}$ north-east of Sukkertoppen.

The reconnaissance mapping programme will be completed in 1978, when the area north of Evighedsfjord as far as latitude $66^{\circ} 45^{\prime} \mathrm{N}$ will be mapped.

\section{Rock units}

Units belonging to the Isua supracrustals, Akilia association (McGregor \& Mason, 1977) and Amîtsoq gneisses (c. 3750 m.y. old) mapped in 1976 in the Godthåbsfjord region (Allaart et al., 1977) have not been recognised in the Sukkertoppen region, except probably in a localised occurrence east of Majorqaq (see R. P. Hall, this report). 